УДК 001.89:338.4:[004+007+654.19+655.1]

( Л. А. Швайка, к.е.н., доцент, Українська академія друкарства, Львів, О. В. Мельников, к.т.н., докторант, ДНну «Академія фінансового управління", Київ,

Е. П. Семенюк, д.філософ.н., професор, Національний лісотехнічний університет України, Львів

\title{
ІНФОРМАЦІЙНА СФЕРА: СТАНОВЛЕННЯ ТА РОЗВИТОК ЕКОНОМІЧНИХ ДОСЛІДЖЕНЬ ВИДАВНИЧО-ПОЛІГРАФІЧНОЇ ГАЛУЗІ УКРАЇНИ (до постановки питання)
}

Автори на прикладі науки, що вивчає економіку інформаційної сфери та її складових, хотіли показати, як відбувається фундаменталізація науки, що на перший погляд є суто прикладною. Цей процес полягає у зростанні питомої ваги її теоретичних складових, удосконаленні поняттєвого й концептуального апарату, побудові моделей ії розвитку, виявленні законів її функціонування i, як наслідок, в отриманні нового методологічного знання. Необхідною умовою цього процесу є також наявність відповідних наукових шкіл. Аналіз питань, пов'язаних із діяльністю наукових шкіл, варто вести за схемою "теорія-школа-напрям-течія", де кожна наступна складова ширша від попередньої. Утім, дослідники не завжди чітко дотримуються необхідної субординації в термінології: поняття теорій, шкіл і напрямів часто змішуються й ототожнюються. Окрім того, не завжди робиться наголос на тривалості та спадкоємності наукових колективів.

У нашому випадку дослідження ведуться протягом вісімдесяти років. Результатом цієї діяльності (в межах наукового напряму «Економічні дослідження видавничо-поліграфічної галузі України") стала поява чотирьох наукових шкіл професорів А. М. Левіна, Р. М. Машталіра, П. Ю. Бєлєнького та академіка М. І. Долішнього. Комплексний системний підхід до вирішення проблем видавничо-поліграфічної галузі, автоматизовані системи управління виробництвом, моделювання виробничих систем - ось далеко не повний перелік напрямів досліджень, які мають важливе наукове та прикладне значення.

Ключові слова: інформаційна сфера; видавничо-поліграфічна галузь; наукова школа; прикладні та фундаментальні дослідження.

Постановка проблеми

Наука перебуває в процесі постійного оновлення і самооновлення. Прогрес науки має харак- тер одночасно неперервного накопичення знань і періодичного заперечення застарілих поглядів, теорій і вчень. Революційні

(ㄷ) $2017 \mathrm{p}$. 
зміни в науці детермінують якісні зрушення в способах виробництва, що, у свою, чергу кардинально змінює оточуючий нас світ.

Передумовою технічного прогресу є науковий прогрес - відкриття нових закономірностей, явищ і властивостей навколишнього світу. Спочатку науковий прогрес - це накопичення емпіричних даних про явища та властивості оточуючого світу, пізніше - накопичення наукових знань. Інший бік справи полягає у впливі науково-технічної революції (НTP) на розвиток самої науки, як особливого соціального інституту, на трансформацію особливостей сучасного наукового знання, його форм і видів, засобів пізнання.

\section{Аналіз попередніх досліджень}

Останніми роками вітчизняних дослідників найбільше цікавлять інституціональні зміни, що відбуваються у вітчизняній науці [1-3], можливості оцінки результатів наукової діяльності $[4,5]$ і підходи до її фінансування $[6,7]$. Історії та методології вітчизняної економічної науки приділяється значно менше уваги. Ще менше пощастило вивченню наукових економічних досліджень окремих галузей господарювання.

\section{Мета роботи}

Кардинальні перетворення в соціально-економічній сфері країни, інтеграція у світовий економічний простір, необхідність формування ефективної моделі розвитку національної економіки зумовлюють потребу в узагальнен- ні та науковому аналізі здобутків вітчизняної економічної думки, вивченні досягнень наукових економічних шкіл і окремих учених. Сучасна вітчизняна економічна наука і освіта мають базуватися на адекватному відображенні нових реалій життя та знанні власної інтелектуальної спадщини.

Автори на прикладі науки, що вивчає економіку інформаційної сфери та її складових [8], хочуть показати, як відбувається фундаменталізація науки, що на перший погляд є суто прикладною. Цей процес полягає у зростанні питомої ваги ії̈ теоретичних складових, удосконаленні поняттевого й концептуального апарату, побудові моделей її розвитку, виявленні законів її функціонування і, як наслідок, в отриманні нового методологічного знання. Необхідною умовою цього процесу $є$ також наявність відповідних наукових шкіл.

Інституціональні засади економічних досліджень видавничополіграфічної галузі

Фундаментальні та прикладні дослідження, а також експериментальні (дослідно-конструкторські) розробки у своїй діалектичній єдності становлять цілісний сплав комплексного переходу від науки до соціальної практики. Термін наука вживається, зазвичай, коли мова йде про: закони природи та суспільства, методи використання цих законів в діяльності людини чи для позначення галузі господарювання, результатом діяльності якої $\epsilon$ отримання нових знань. Щодо інституціонального виміру цієї проблеми, то раніше 
дослідниками виділялися академічний, вузівський, галузевий і індустріальний сектори науки (наприклад, [9]). Сьогодні логічніше говорити про академічний, університетський і промисловий сектори науки, де ведуться наукові дослідження.

В академічному секторі науки ведуться роботи з: визначення тенденцій розвитку світової економіки; вивчення проблем макроекономічного та регіонального рівнів; формування проектів державних програм, стратегій розвитку національної економіки та її певних сфер; розробки рекомендацій для центральних органів виконавчої влади. Ці дослідження здійснюються в установах НАН України та галузевих академій наук, вони тісно пов'язані з економічними кафедрами класичних університетів, їх інформаційно-комунікаційні зв'язки $€$ постійними, міцними й відносно матеріально забезпеченими.

Завданням академічного сектору науки $є$ максимальне використання об'єктивно притаманних йому переваг. Головною з них $\epsilon$ можливість перерозподілу за необхідності наявних матеріальних і людських ресурсів з урахуванням науково обґрунтованих прогнозів рівня науково-технічного прогресу. Взаємопроникним $є$ також зв'язок академічного та інших секторів науки з сумісного використання матеріально-технічної бази академічного сектору науки.

Зв'язок університетського сектору української науки з іншими секторами полягає у першу чергу в розширеному відтворенні кадрів спеціалістів і наукових працівників. Університети завжди були і залишаються провідними осередками розвитку фундаментальних економічних досліджень, що розглядаються як загальнотеоретична і методологічна база для господарської практики. Важливою особливістю університетського сектору науки $є$ універсальний, всезагальний характер наукової та педагогічної діяльності практично з усіх галузей сучасного знання. За універсальністю у цьому відношенні університетський сектор можна порівняти хіба що з академічним.

У процесі комплексного використання наукового потенціалу університетського сектору науки важливою перевагою вищої школи, порівняно з академічними інститутами, є більш широка географія, адже в усіх обласних центрах країни, і навіть деяких районних, створені вищі навчальні заклади. У процесі випуску спеціалістів у відповідності зі специфікою економічних районів формуються наукові інтереси колективів. Перевагою вищої школи, що не завжди використовується, є можливість в існуючих вузах у разі потреби порівняно швидко розпочати підготовку фахівців з нових спеціальностей. Успішне розв'язання завдань, що стоять перед університетами, залежить від того, наскільки оптимальним буде поєднання навчальної та наукової роботи.

Промисловий сектор науки відповідає за реалізацію науково-технічних досягнень, від його потенціалу залежить їх втілення у виробництво. На відміну від академічного та університетського секторів науки, промисловий сектор науки безпосередньо змикається 3 вітчизняним господарством. 
Свого часу у більшості галузей господарювання були створені власні науково-дослідні установи. Поряд із дослідницькою роботою ці інститути обслуговували й обслуговують підприємства відповідно до їх виробничих потреб. Частина цих науководослідних інститутів (НДІ) входить до виробничих і науково-виробничих об'єднань, їх доповнюють конструкторські та технічні бюро. Особливістю більшості галузевих НДІ порівняно з вищими навчальними закладами $є$ наявність у них дослідно-експериментальних виробництв. Ці організації ведуть розроблення принципово нових проектів, конструкцій та технологічних процесів, знаходять нові природні ресурси та синтетичні матеріали. Це в ідеалі має забезпечувати випереджувальні темпи розвитку галузей по відношенню до процесів фізичного та морального старіння обладнання та технологій. Сьогодні через брак інвестицій це, звичайно, не завжди вдається. Окрім того, промисловий сектор науки завжди був гірше забезпечений висококваліфікованими кадрами дослідників, але навіть за цих непростих умов він проявляє себе як сектор багатодисциплінарних наукових досліджень.

Наукові економічні дослідження вітчизняної видавничо-поліграфічної галузі проводилися в організаціях з усіх вищеокреслених груп, але з інституціональної точки зору вони мали свої відмінності, пов'язані із особливостями організації й розташування галузевих вищих навчальних закладів і науково-дослідних установ (рис.), про що мова піде нижче.
В СРСР було лише два вищих автономних навчальних заклади (у Москві та Львові), які готували спеціалістів для потреб видавничої справи, поліграфії та книгорозповсюдження. Історично склалося так, що вітчизняним центром наукових економічних досліджень видавничо-поліграфічної галузі $€$ Українська академія друкарства (до 1994 року - Український поліграфічний інститут ім. Івана Федорова), що була створена 1930 року у Харкові. 1932-го року на базі науково-дослідної кафедри інституту було організовано Всеукраїнський науководослідний інститут поліграфії (нині Український науково-дослідний інститут поліграфічної промисловості (УНДІПП) ім. Т. Г. Шевченка), значна частина працівників якого продовжувала за сумісництвом працювати й у навчальному інституті [10].

У 1945 році навчальний, а 1948-го й науково-дослідний інститути було переведено до Львова. Наприкінці 50-х років при інституті Івана Федорова було створено Київський вечірній факультет (тепер Видавничо-поліграфічний інститут КП ім. Ігоря Сікорського) [11, 12].

у 1960-1980 рр. на базі Львівської книжкової фабрики «Атлас» Республіканського виробничого об'єднання «Поліграфкнига» діяла Республіканська нормативно-дослідна станція Державного комітету УРСР у справах видавництв, поліграфії і книжкової торгівлі, що займалася дослідженням і встановленням норм часу і виробітку на процеси поліграфічного виробництва (до роботи якої активно залучалися науковці 3 полігра- 
фічного інституту). У 1980-ті рр. діяла філія кафедр технології виготовлення друкарських форм та економіки і організації поліграфічної промисловості поліграфічного інституту Івана Федорова на базі УНДіПП. Працювали також філії кафедр інституту Івана Федорова на інших підприємствах галузі.

В Києві функціонувало ще два науково-дослідних інститути: філія Всесоюзного НДІ комплек- сних проблем поліграфії (нині Український науково-дослідний інститут спеціальних видів друку УНДІСВД) і ГіпроНДІ поліграфії, що займався проектуванням i реконструкцією поліграфічних підприємств. У цих НДІ також працювали в основному випускники і науковці 3 інституту Івана Федорова [13].

На початковому етапі існування перелічені вищі навчальні заклади та науково-дослідні інститути

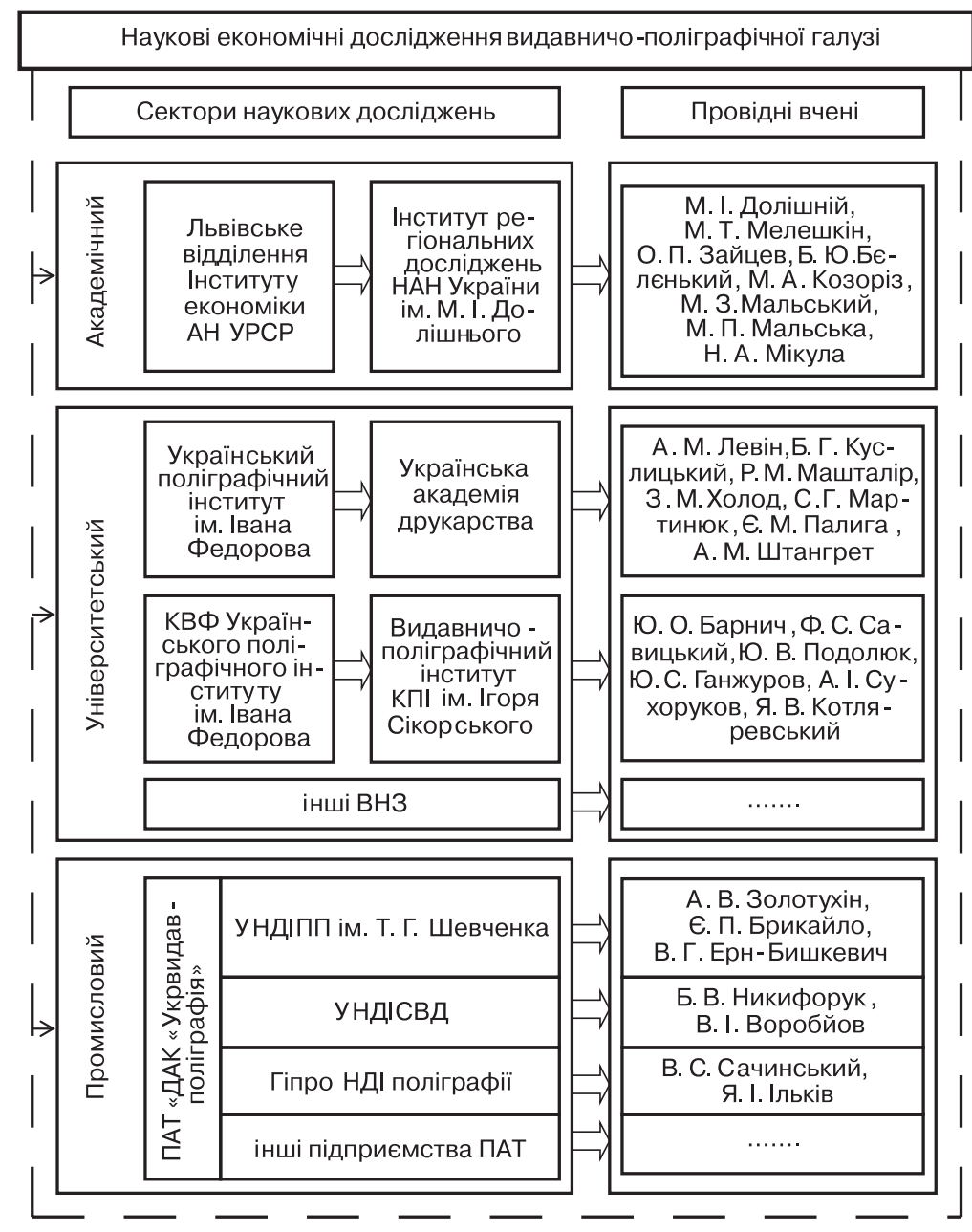

Структурно-організаційні засади наукових економічних досліджень видавничо-поліграфічної галузі 
являли собою невеликі колективи, перед якими ставилися завдання підготовки кваліфікованих інженерних кадрів і надання технічної допомоги поліграфічним підприємствам республіки. Діяльність інженерно-економічного факультету Українського поліграфічного інституту та групи організації праці науково-дослідного інституту в 1930-і рр. нерозривно пов'язана з іменем Абрама Марковича Левіна [14, С. 23-32; 15, С. 250-252], якого можна з повним правом назвати фундатором економічних досліджень видавничо-поліграфічної галузі України. У передвоєнні роки під його керівництвом розроблялися основні принципи проектування процесів поліграфічного виробництва, проводилися роботи з технічного нормування, організації праці на поліграфічних підприємствах і технікоекономічного аналізу їх діяльності. У перші повоєнні роки під його ж керівництвом виконувалися дослідження з удосконалення форм спеціалізації та кооперування поліграфічного виробництва.

Узагальнюючи основні теми наукових економічних досліджень проблем видавничо-поліграфічної галузі, що проводилися в наступні роки, подамо їх у вигляді таблиці (табл. 1), яка спростить нам процес їх аналізу.

Становлення економічних досліджень видавничо-поліграфічної галузі

у 1950-60-і рр. постало завдання розвитку прикладних наукових досліджень, що могли бути впроваджені в промислових масштабах: багато уваги приділялося розробленню та впровадженню науково-обґрунтованих методів організації виробництва і праці, а саме нормуванню та організації праці, потокової організації виробництва в брошурувальнопалітурних цехах, механізації та автоматизації виробництва. Крім того, відпрацьовувалися заходи з усунення виробничих втрат, підвищення потужності діючого устаткування, кращої організації робочих місць та їх обслуговування.

Потім розпочали досліджувати питання спеціалізації підприємств, кооперування виробництв, оптимізації ресурсів, розвитку господарського розрахунку, запровадження системи обліку, упорядкування внутрішньозаводського планування, нормування обігових коштів, удосконалення оформлення книг, підвищення якості друкованої продукції.

Керівництво усіма цими роботами здійснював А. М. Левін. Працівниками кафедри економіки і організації поліграфічного виробництва Українського поліграфічного інституту ім. Івана Федорова були розроблені перші положення про нормування праці у поліграфії, удосконалена методика вивчення витрат часу на робочих місцях, які обслуговували бригади робітників, створені довідники технічно обґрунтованих норм. Спільно 3 науковцями Москви, Ленінграда і Києва працівники кафедри провели велику роботу зі створення прейскурантів гуртових цін на продукцію поліграфічних підприємств. Це сприяло значному удосконаленню економічної роботи на підприємствах, підвищенню ефективності вироб- 
ництва, стало базою для організації господарського розрахунку. У наукових дослідженнях кафедри чільне місце посіли роботи з удосконалення планування, обліку і калькулювання собівартості продукції: була розроблена «ннструкція по плануванню, обліку і калькулюванню собівартості продукції», яка лягла в основу всіх наступних нормативних документів з управління витратами поліграфічного виробництва.

Дослідження $з$ планування навели на думку про доцільність широкого застосування на поліграфічних підприємствах нормативного методу обліку витрат на виробництво. Його впровадження давало змогу тісно пов'язувати оперативні плани з техпромфінпланом, постійно контролювати стан його виконання та передбачити економічні результати ще до запуску замовлень у виробництво. Запропоновану методику успішно використали на вітчизняних підприємствах, які запроваджували автоматизовані системи управління виробництвом.

Надзвичайно важливим для організації поліграфічного виробництва було розроблення проекту потокових ліній, які сприяли підвищенню виробничої потужності брошурувально-палітурних цехів і значному скороченню тривалості виробничого циклу, росту продуктивності праці. Методика розрахунку потокових ліній була широко застосована при їх проектуванні в умовах Київської книжкової фабрики, де функціонувало декілька потокових ліній для випуску книжкової продукції різних обсягів, форматів, способів скріплення книжкових блоків. Усі великі вітчизняні поліграфічні підприємства застосовували цю методику.

Тоді ж науковці зосередили свої зусилля на виявленні внутрішніх резервів зниження собівартості видавничої продукції, підвищення іï рентабельності шляхом удосконалення редакційно-видавничого процесу, раціонального використання матеріальних і трудових ресурсів, удосконалення зв'язків між видавництвами і поліграфічними підприємствами. Подальший розвиток цих досліджень зумовлений застосуванням фотоскладальної, а далі - комп'ютерної техніки, що створювало реальні передумови для перенесення процесу складання і верстання з друкарень у стіни видавництва. Це давало можливість уникнути дублювання окремих процесів, знизити витрати на підготовку видань і забезпечити їх оперативний випуск.

Активний розвиток науковотехнічного прогресу в 1970-і рр. спричинив потребу у визначенні рівня механізації та автоматизації виробництва, дослідження неперервності, застосування варіантного методу обґрунтування технічних рішень, прогнозування напрямів розвитку поліграфічної техніки. Дослідження і застосування фотополімерних форм в друкарському виробництві зумовили потребу в економічному обґрунтуванні варіантів їх виготовлення для друкування різної продукції.

Необхідно відзначити, що особливу роль в процесі теоретизації науки в епоху НТР відіграють формування і розвиток системного 


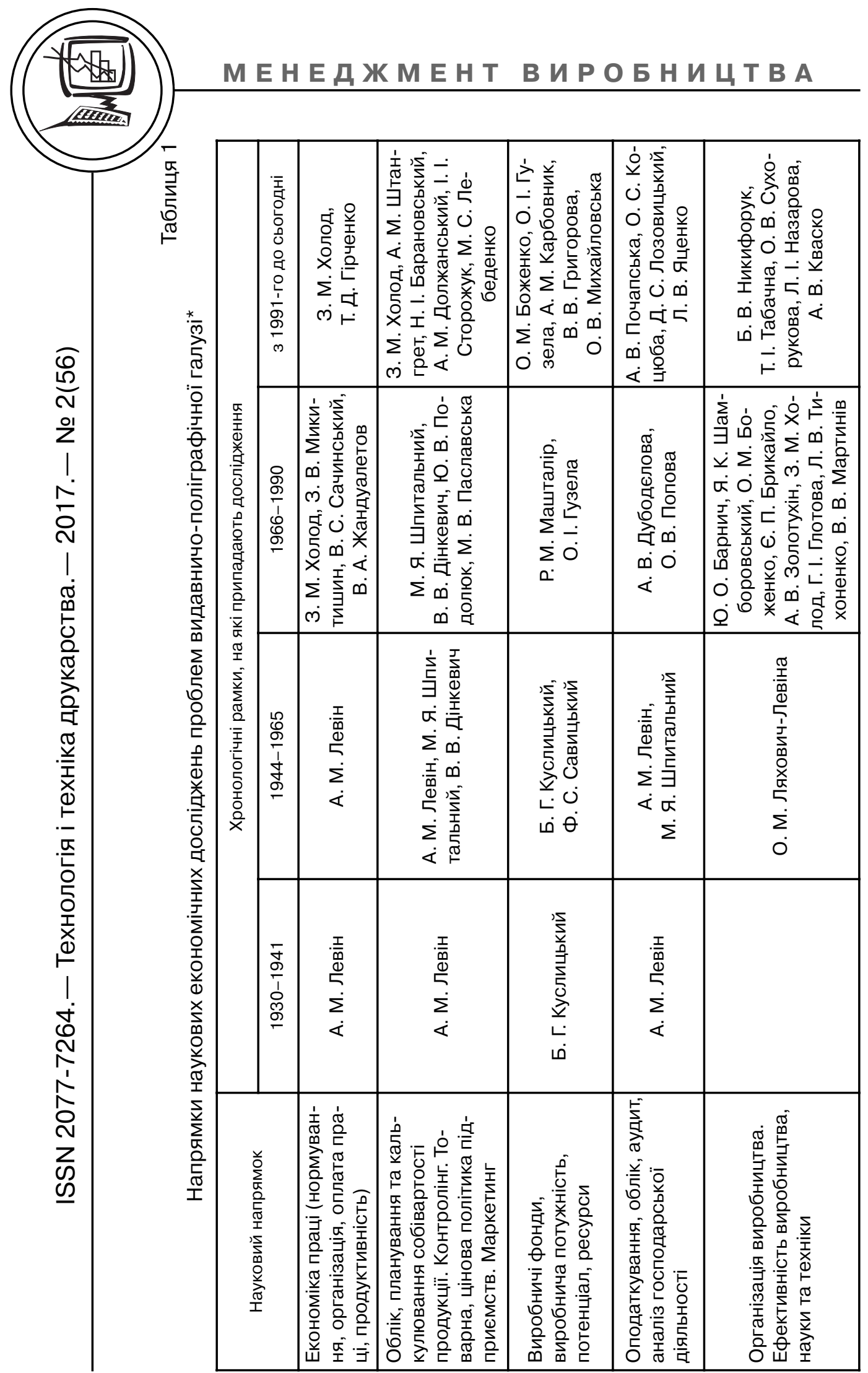




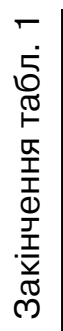

\begin{tabular}{|c|c|c|c|c|c|}
\hline 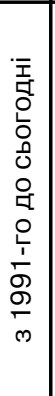 & 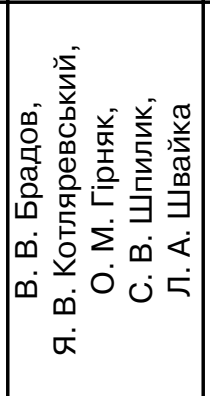 & 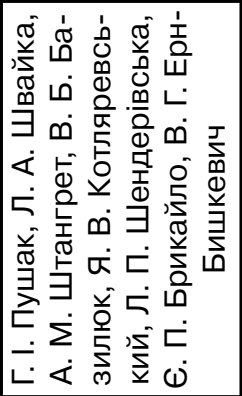 & 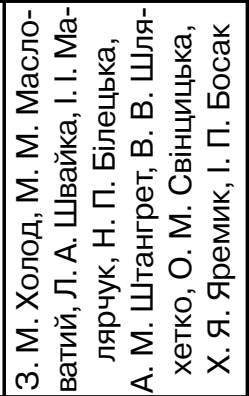 & 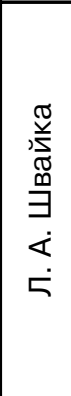 & 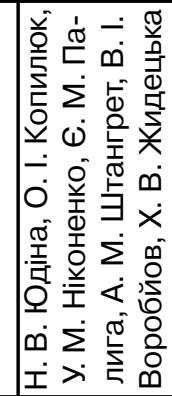 \\
\hline & & & & & \\
\hline
\end{tabular}

8

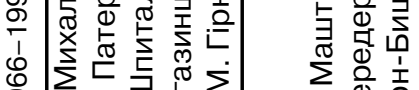

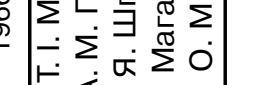

$\sum^{\infty} \stackrel{0}{1} \frac{1}{1}$

을

4

$\dot{\Sigma}$ ᄃ

宁 $\dot{\square}$

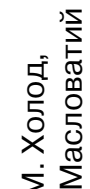

疋

ヒே

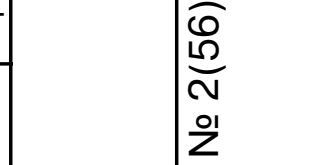

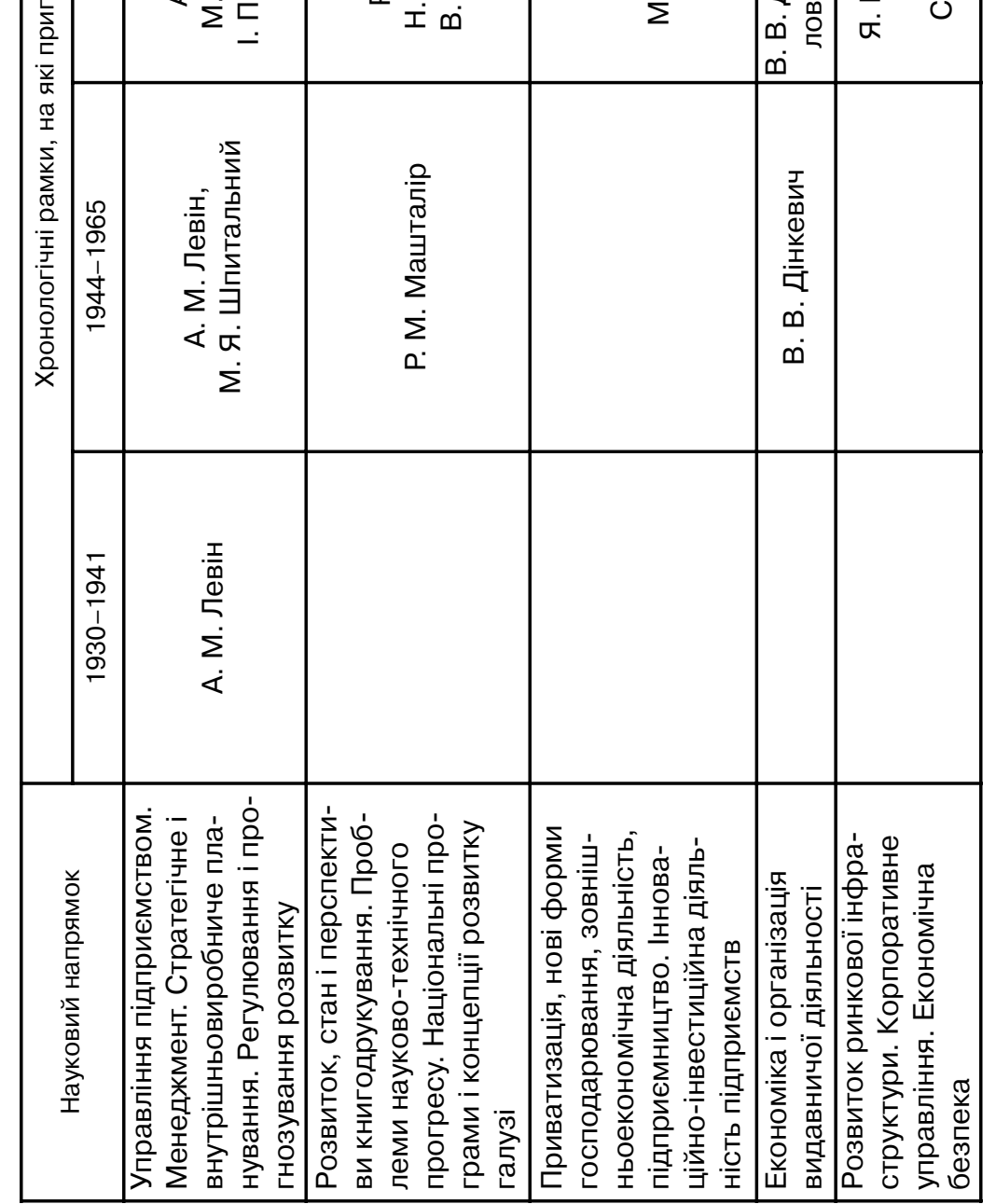

z 
підходу [16]. Справа в тому, що за своєю суттю теорія завжди носить глибоко системний характер, саме в ній в першу чергу з найбільшою повнотою і послідовністю виражається системність наукового знання в цілому (як відображення системності пізнаваного світу). Ця властивість $\epsilon$ визначальною для наукової теорії в усі часи з моменту зародження теоретичного рівня знання як особливого наукового феномена. Однак системність теорії, ступінь і сам характер цієї властивості, звичайно ж, не були чимось застиглим, вони якісно видозмінювалися з часом. I ця внутрішня трансформація самого теоретичного знання в напрямку безперервного поглиблення його системності, і швидке збільшення питомої ваги, і значення теорії в загальному арсеналі засобів науки (які особливо помітно проявилися за останні десятиліття, в умовах НТР) в значній мірі були органічно пов'язані саме з конституюванням системного підходу як загальнонаукового явища.

Ще одна важлива сторона питання полягає в еволюції засобів і механізмів формування теорії. Теоретичне мислення, як специфічний гносеологічний феномен, вимагає для своєї реалізації специфічних засобів, власної мови, істотно відмінної від мови емпіричного рівня наукового пізнання. Одиницями такої мови служать прості і складні теоретичні конструкти, з яких складається тканина теоретичного знання. Отже, процес розвитку теорії - це одночасно і процес розвитку інституту теоретичних конструктів, збільшен- ня їх якісного розмаїття, виникнення все нових і більш складних їх видів. Ця обставина внутрішньо пов'язана ще з однією важливою особливістю сучасного наукового знання - 3 поглибленням його математизації $[17,18]$.

Тож новим імпульсом у розвитку галузевої економічної науки стало дослідження економічних проблем науково-технічного прогресу в єдиному комплексі «наука-техніка-виробництво-споживач» з використанням системного підходу. Цей підхід для аналізу ситуації у видавничо-поліграфічному комплексі першим почав застосовувати Роман Михайлович Машталір [19], який завдяки своїй енергії та глибокому баченню проблем розвитку видавничо-поліграфічної галузі став у 1970-1980-і рр. лідером досліджень його проблем. Професор Р. М. Машталір бачив залежність результатів господарювання від чисельних факторів. Визначити вплив кожного з них на результати за допомогою традиційних статистичних методів практично неможливо, тому він стає ініціатором активного використання методів математичного моделювання для аналізу ситуації у видавничо-поліграфічному комплексі.

Наукові дослідження заслуженого діяча науки та техніки УРСР професора Машталіра та його учнів відбувалися за трьома основними напрямами: розвиток і перспективи книгодрукування в Україні; ефективність використання виробничих фондів поліграфічних підприємств; економічні проблеми науково-технічного прогресу в поліграфії. Учні професора демонстрували 
хороші результати роботи: активно публікувалися, виступали на наукових конференціях, впроваджували результати досліджень у виробництво та навчальний процес. Усе це стало вагомою підставою для відкриття в 1983 р. при Українському поліграфічному інституті ім. Івана Федорова спеціалізованої вченої ради з захисту дисертаційних робіт на здобуття наукового ступеня кандидата економічних наук зі спеціальностей 08.00.05 - економіка, планування і організація управління народним господарством і його галузями та 08.00.21 економіка, планування і організація управління промисловістю і її галузями [20]. Відкриття ради при поліграфічному інституті значно полегшило процес проходження атестації наукових кадрів вищої кваліфікації. Однак передчасна смерть P. М. Машталіра у 1990 р. поступово призвела до згортання діяльності ради та припинення їі діяльності.

Р. М. Машталір розумів, що підготовка кадрів і розвиток досліджень на належному рівні неможливі без наукових контактів, обміну інформацією з колегами з інших наукових осередків. Така творча наукова співпраця склалася з ученими Львівського відділення Інституту економіки АН УРСР (нині Інститут регіональних досліджень НАН України ім. М. І. Долішнього): в академії друкарства в різний час працювали академік НАН України, заслужений діяч науки та техніки УРСР, лауреат Державної премії України в галузі науки і техніки, премії АН УРСР ім. О. Г. Шліхтера та премії НАН України ім. М. І. Туган-Барановського М. І. Долішній, член-кореспондент АН УРСР М. Т. Мелешкін, професор, лауреат премії АН УРСР ім. О. Г. Шліхтера П. Ю. Бєлєнький, професори О. П. Зайцев, М. А. Козоріз, Н. А. Мікула.

Поряд із дослідженнями у Львові, наукові економічні дослідження проблем видавничополіграфічної галузі проводилися й на вечірньому факультеті Українського поліграфічного інституту ім. Івана Федорова в Києві. Особливо вони інтенсифікувалися після 1975 р., коли на роботу туди перейшов учень А. М. Левіна заслужений працівник вищої школи УРСР Юрій Олександрович Барнич [14, С. 73-80; 15, С. 56-57]. Юрію Олександровичу вдалося об'єднати зусилля співробітників кафедри організації видавничої справи, поліграфії та книгорозповсюдження Київського факультету, науковців Державного комітету УРСР у справах видавництв, поліграфії і книжкової торгівлі, галузевих науково-дослідних інститутів, провідних фахівців великих видавництв, поліграфічних підприємств і підприємств книгорозповсюдження. Деякі з них брали участь в навчальному процесі та наукових дослідженнях кафедри. Згодом колектив кафедри поповнився науковцями зі Львова. Науковці кафедри працювали над розробленням і впровадженням програм і рекомендацій для підприємств галузі щодо вдосконалення організації поліграфічного виробництва, підвищення його ефективності (спочатку для підприємств РВО «Поліграфкнига», потім для ДП «Преса України» Державного управління справами Президента України, 
ПрАТ «Видавництво «Київська правда» та багатьох інших). Колектив кафедри проводив дослідження в напрямі ефективності технічного прогресу, обґрунтування інвестицій та інновацій, організації виробництва і праці, стану книговидання та перспектив його розвитку. Науковці кафедри здійснюють моніторинг і аналіз книжкового ринку навчальної літератури, вивчають попит на українську книгу. Сьогодні кафедра організації видавничої справи, поліграфії та книгорозповсюдження Видавничо-поліграфічного інституту НТУУ «КПІ ім. Ігоря Сікорського» під керівництвом заслуженого працівника культури України професора Юрія Семеновича Ганжурова дещо змінила акценти наукового пошуку відповідно до потреб часу й продовжує успішно працювати.

Розповідь про розвиток наукових економічних досліджень видавничо-поліграфічної галузі була би неповною без загальної характеристики наукових економічних досліджень, що виконувалися в УНДІППі, що майже двадцять років очолював учень Р. М. Машталіра Анатолій Васильович Золотухін [14, С. 73-80].

У першій половині 1960-х рр. в НДІ проводилися дослідження проблем організації, планування і управління поліграфічним виробництвом, які з часом набули планомірного цілеспрямованого характеру.

у 1971 р. була визначена спеціалізація науково-дослідних інститутів в поліграфічній промисловості і УНДІПП став головною організацією в СРСР з розробки і впровадження у виробництво досліджень та інновацій в галузі високого способу друку, тоді ж був введений в дію обчислювальний центр НДІ. Відповідно, в УНДІППі проводили роботи з науково-економічного прогнозування розвитку високого друку 3 використанням сучасних наукових математичних методів і електронно-обчислювальної техніки.

Науковці УНДІПП у 19701980-і рр. успішно досліджували проблеми удосконалення оперативно-календарного планування і управління книжковим виробництвом, проводили аналіз проблем створення і впровадження автоматизованих систем управління виробництвом (АСУВ) В поліграфії. Була розроблена й здана в промислову експлуатацію перша в країні автоматизована система управління (АСУ) дискретним виробництвом «АСУВ-Атлас» (Львівська книжкова фабрика «Атлас» РВО «Поліграфкнига»). Система вигідно відрізнялася від інших АСУ поліграфічними підприємствами, які функціонували тоді в країні, створеним оптимальним складом функціональних підсистем 3 головною підсистемою оперативно-календарного управління книжковим виробництвом з використанням запропонованої системи сітьового планування, значним вмістом оптимізаційних задач, спеціальним математичним забезпеченням, єдиною інформаційною базою даних, експлуатацією обчислювальних центрів колективного користування. Автоматизована система «АСУВ-Атлас» демонструвалася у 1981 р. на ВДНГ СРСР і була відзначена золотою медаллю 
виставки. Про належний рівень виконаних досліджень свідчить присвячена їх вивченню Всесоюзна науково-технічна конференція «Достижения науки и пути ускорения научно-технического прогресса в области высокой печати» (1982), передрук публікацій інституту у відомчих журналах Німеччини, Польщі і Чехословаччини.

У 1980-і рр. в НДІ також були виконані теми за народногосподарськими планами СРСР, УРСР, РРФСР і БРСР. Велика увага приділялася удосконаленню методики визначення ефективності техніки і технології, комплексної оцінки ефективності досліджень та інновацій в поліграфії.

На початку 1990-х рр. науковці УНДІППу активно працювали над розробленням широкомасштабної Державної програми розвитку національного книговидання і преси на період до 2000 року. Використовуючи комплексний системний підхід до її формування, вдалося розробити надзвичайно цікавий і актуальний документ, який охоплював не лише видавничо-поліграфічний комплекс, а й усі дотичні до нього галузі - поліграфічне машинобудування, виробників паперу, картону, фарби та інших витратних матеріалів, галузеву освіту, науку, сферу книгорозповсюдження, заходи впливу на авторське й читацьке середовище. Програму було затверджено Указом Президента України від 28.02. 1995 р. № 158/95 [21]. Упродовж трьох років Державна програма розвитку національного книговидання і преси реалізовувалася і мала державну підтримку.
Однак через ряд причин об'єктивного і суб'єктивного характеру вона перестала фінансуватися державою і була реалізована частково.

у 2000-х рр. УНДІпП ім. Т. Г. Шевченка очолювала відомий у галузі економіст Валентина Георгіївна Ерн-Бишкевич, що доклала значних зусиль для продовження наукових досліджень в УНДІППі. На замовлення Державного комітету телебачення і радіомовлення України науковці НДІ розробили і вдосконалили нормативну базу підприємств галузі - трудові норми і нормативи, інструкції з обліку, планування та калькулювання собівартості видавничої та поліграфічної продукції тощо [22].

Економічні дослідження видавничо-поліграфічної галузі проводилися також в УНДІСВ і ГіпроНДІ поліграфії, що сприяло творчим контактам і розширенню тематики наукових досліджень.

Сучасний етап фундаментальних $і$ прикладних економічних досліджень видавничо-поліграфічної галузі

Кардинальні зміни 1990-х рр. в суспільстві, що супроводжувалися роздержавленням і приватизацією господарюючих структур, високим рівнем інфляції, загостренням конкуренції тощо, спричинили в суспільстві певну втрату інтересу до науки і науково-технічної діяльності. Зменшилося, а в багатьох ситуаціях припинилося державне фінансування науково-дослідних робіт.

За таких непростих умов наукові економічні дослідження видавничо-поліграфічної галузі в Українській академії друкарства 
у 1990-і рр. продовжилися під керівництвом учениці професора Машталіра Зеновії Михайлівни Холод [23]. За цей період на замовлення Державного комітету телебачення і радіомовлення України, УНДІСВД, Парламентського видавництва, інших підприємств було виконано півтора десятки науково-дослідних тем. Науково-дослідна робота кафедри стала базою для проведення наукових і науково-практичних конференцій та семінарів різного рівня (міжнародних і всеукраїнських).

Науковці кафедри брали участь у розробленні проекту Закону України «Про оренду», систематизували законодавчі та нормативні документи з розвитку нових форм господарювання в Україні, досліджували питання, пов'язані з приватизацією підприємств, розвитком малих форм господарювання, формуванням стратегії розвитку місцевої поліграфії, ефективного використання потенціалу підприємства, формування ринкових цін і вдосконалення ціноутворення, розвитку зовнішньоекономічних зв'язків, обґрунтування проектів розвитку структур видавничополіграфічної галузі, їх економічної безпеки, конкуренції та фінансового стану.

Науковці продовжували досліджувати і традиційні проблеми, пов'язані з удосконаленням організації праці, її мотивації та оплати, напрямками науковотехнічного розвитку, ефективним використанням трудових і матеріально-технічних ресурсів тощо. Продовжилася робота 3 виконання госпдоговірної тематики на замовлення підприємств галузі, зокрема, видавництв Дніпропетровська та Хмельницького, ряду міських і районних друкарень Херсонської, Миколаївської та Одеської областей.

Час вимагав також внесення істотних змін в навчальний процес, тому на базі кафедри економіки, обліку і аудиту у видавничо-поліграфічному комплексі (до того кафедра - економіки і організації поліграфічної промисловості) академії друкарства створюються дві кафедри: економіки підприємства та маркетингу та обліку і аудиту. Кожна з них почала формувати свою наукову тематику, однак дослідження соціально-економічних проблем галузі здійснювалися спільними зусиллями.

Новий поштовх науковим економічним дослідженням проблем видавничо-поліграфічної галузі надав учень академіка М. І. Долішнього Євген Миколайович Палига [24], що 2004 р. перейшов на роботу до академії друкарства й очолив кафедру економіки підприємства та маркетингу. Багаторічний керівник промислових підприємств Львова, він добре розумів значення науки в науково-технічному поступі. Він також запросив до роботи в академії професорів $H$. A. Miкулу та Н. І. Чухрай. Дещо по-іншому організував науково-дослідну роботу кафедри - вийшов за межі розв'язання галузевих проблем (дослідження, пов'язані 3 економічною безпекою, банкрутством, маркетинговою, торгівельною діяльністю, удосконаленням обліку, звітності, оподаткування фізичних і юридичних осіб, створенням кластерів, моделюванням виробничих систем), 
оновив колектив кафедри молодими випускниками інших навчальних закладів, активізував роботу з підготовки та захисту дисертаційних робіт.

Інший напрямок в розвитку економічних досліджень видавничо-поліграфічної галузі пов'язаний $з$ ім'ям іншого учня М. І. Долішнього Андрія Михайловича Штангрета [25], що у 2011 р. очолив кафедру обліку і аудиту академії друкарства та за короткий період часу перетворив іï на сучасний науково-освітній підрозділ академії, забезпечений науково-педагогічним персоналом вищої кваліфікації, що проводить ґрунтовні наукові дослідження. Науковці кафедри активно розробляють наукові теми: стан, проблеми та напрямки вдосконалення обліку, аналізу та аудиту підприємницьких структур видавничо-поліграфічної галузі та моделювання механізмів управління економічною безпекою підприємства. На кафедрі також працює інший відомий учений професор О. І. Копилюк.

Аби краще зрозуміти кількісні показники діяльності провідних науковців й учених, що досліджували економіку видавничополіграфічної галузі, покажемо їх у вигляді таблиці (табл. 2).

\section{Висновки}

Проведений аналіз становить інтерес не тільки для тих, хто вивчає історію досліджень економіки видавничо-поліграфічної галузі, адже аналізуючи шлях їx становлення і розвитку бачимо, що вчені, які працювали у цій царині, заклали добрі підвалини для майбутніх дослідників. Бачимо, що центром наукових економічних досліджень видавничо-поліграфічної галузі стала Українська академія друкарства, учені й науковці якої, окрім підготовки фахівців для потреб галузі, активно займалися науковими дослідженнями та поступово від розв'язання науково-прикладних проблем перейшли до фундаментальних досліджень [26-29].

Традиційно розподіл наук на фундаментальні та прикладні здійснюють у контексті протиставлення «теоретичне-емпіричне» та «теоретичне-практичне» знання, але на певному етапі розвитку науки, як ми бачили вище на конкретному прикладі, у ній поряд із прикладними розділами формуються фундаментальні. В сучасних умовах більшість наукових дисциплін продукують як прикладне так й фундаментальне знання одночасно. Так, в економічній науці, де вона виявляє тенденції й закономірності функціонування економічних систем, ми маємо справу з фундаментальними дослідженнями, коли ж вона дає рекомендації щодо оптимізації організації праці та підвищення ії продуктивності, ми спостерігаємо очевидно прикладні дослідження.

Окрім того, тісна співпраця академії друкарства з Інститутом регіональних досліджень НАН України ім. М. І. Долішнього, УНДІППом та іншими організаціями підтвердила, що завдяки інтеграції освіти, науки й виробництва можна досягнути значних результатів. Процес інтеграції науки відбувається зверху донизу та стосується всієї структури вітчизняної науки. Існування цієї тенденції дозволяє прогнозувати процеси, що будуть відбуватися 


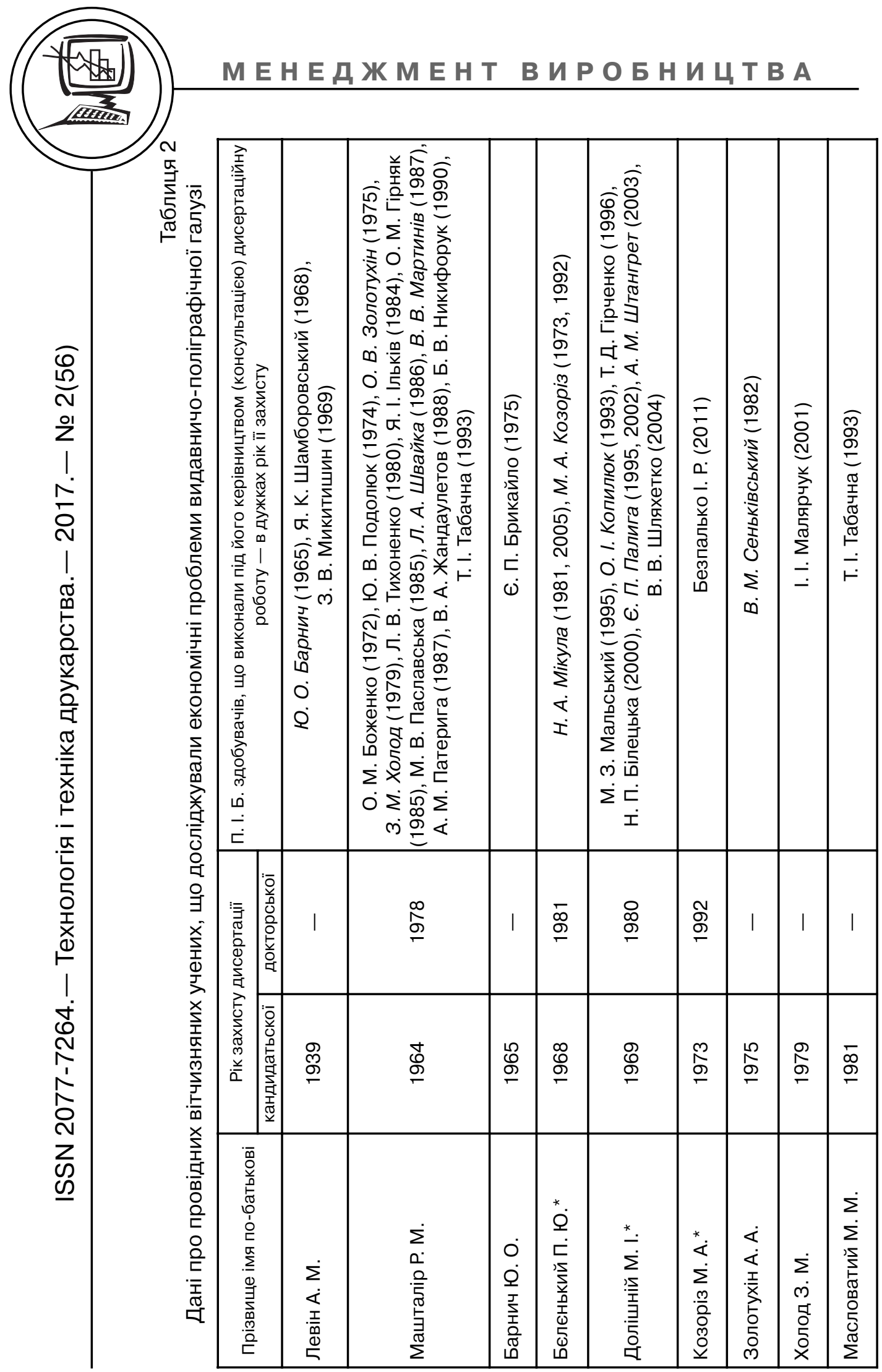




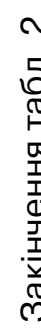

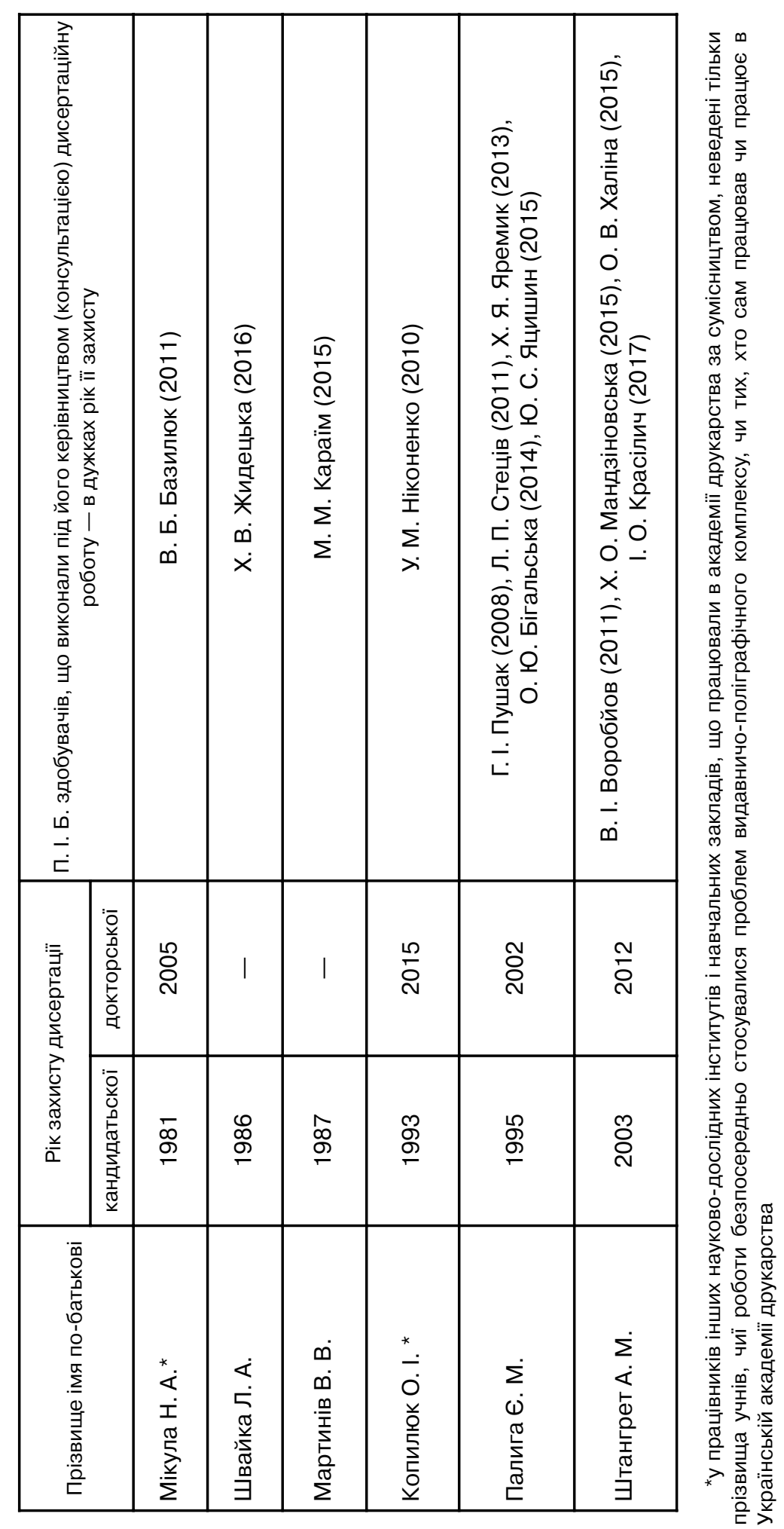
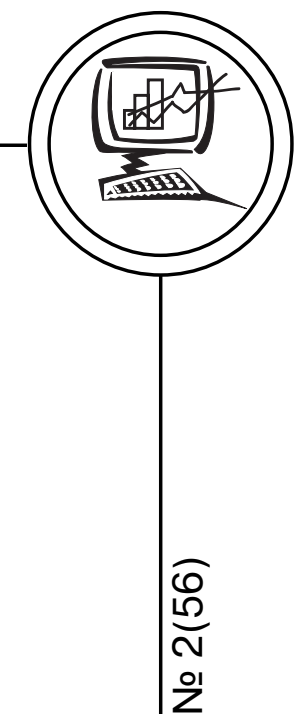
в усіх секторах вітчизняної науки, виходячи з провідного та визначального значення університетського сектора науки. У зв'язку із недостатнім фінансуванням академічного та промислового секторів науки значення університетського сектору науки, як центру, що синтезує досягнення фундаментальних наук, у тому числі й пошукового характеру, у майбутньому очевидно буде тільки зростати.

Принципове значення для вивчення становлення та розвитку економічних досліджень видавничо-поліграфічної галузі України має питання про наукові школи, без яких неможлива генерація нових ідей, виробництво нових знань. Утворення наукових шкіл у процесі виконання економічних досліджень видавничо-поліграфічної галузі відображає взаємодію двох протилежних тенденцій диференціації та інтеграції в науці. $З$ одного боку, утворення кожної наукової школи - це прояв диференціації в певній галузі наукових досліджень; з іншого це інтеграція пізнавально-методологічних і науково-організаційних зусиль більшої чи меншої групи вчених і фахівців-дослідників певного профілю [30].

В основі поділу науки на школи лежать такі ознаки, як особа засновника (засновників), певна географічна чи організаційна єдність учнів і послідовників лідера школи, змістовна, ідейнотеоретична згуртованість членів школи (потрібно додати ще створення наукового напрямку в результаті діяльності школи), громадське визнання результатів діяльності школи на батьківщині та за кордоном [30, С. 84].
Наукові школи формуються, розвиваються і руйнуються під дією об'єктивних обставин. Формування наукових шкіл в економічній науці має давні традиції: кожна наукова школа має певну специфіку створення та функціонування [31-33].

Дослідники [31, С. 9-10] додатково пропонують якісні та кількісні критерії виокремлення наукової школи (наведемо тут найважливіші з них на нашу думку): наукова кваліфікація і склад колективу (мінімальна кількість його членів - 10-12 осіб); спадкоємність поповнення через підготовку наукових кадрів за наявності щонайменше трьох поколінь, пов'язаних ланцюжком «учителіучні»; наявність власного наукового друкованого органу; реалізація наукових результатів на практиці.

У нашому випадку бачимо засновника А. М. Левіна; дослідження здійснюються в межах однієї установи та пов'язаних із нею інституціонально структур; вже понад три покоління зв'язані ланцюжком «учителі-учні» (професори А. М. Левін, Р. М. Машталір, П. Ю. Бєлєнький, академік М. І. Долішній й їх учні, та учні їх учнів). Провідні вчені цього напрямку були відзначені державними й академічними нагородами та преміями, почесними званнями. Є й власний науковий друкований орган (ці функції у різний час виконували): «Наукові записки» академії друкарства (виходили з перервами у 1939-1941, 1947-1962, з 1999 р. до тепер) $[34,35]$ і науково-технічний збірник «Поліграфія та видавнича справа» (виходить з 1964 р.) [36]. Результати проведених дослі- 
джень широко впроваджено у практику діяльності господарюючих суб'єктів видавничо-поліграфічної галузі.

Очевидно, варто погодитися з П. М. Леоненком, що аналіз питань, пов'язаних із діяльністю наукових шкіл, варто вести за схемою «теорія-школа-напрямтечія», де кожна наступна складова ширша від попередньої. Так, наукова школа зазвичай охоплює декілька однотипних, споріднених теорій, а напрями, у свою чергу, - кілька споріднених шкіл. Утім, дослідники не завжди чітко дотримуються необхідної субординації в термінології: поняття теорій, шкіл і напрямів часто змішуються й ототожнюються. Окрім того, не завжди робиться наголос на тривалості спадкоємності наукових колективів [32, С. 44].

У нашому випадку дослідження ведуться протягом вісімдесяти років. Результатом цієї діяльності (в межах наукового напряму «Економічні дослідження видавничо-поліграфічної галузі України») стала поява чотирьох наукових шкіл професорів А. М. Левіна, Р. М. Машталіра, П. Ю.
Бєлєнького та академіка М. І. Долішнього. Комплексний системний підхід до вирішення проблем видавничо-поліграфічної галузі, автоматизовані системи управління виробництвом, моделювання виробничих систем - ось далеко не повний перелік напрямів досліджень, які мають важливе наукове та прикладне значення. Оскільки наукова школа окрім дослідницької функції виконує ще й педагогічну, то необхідно відзначити, що у результаті діяльності цих шкіл було підготовлено майже п'ятдесят докторів і кандидатів наук, які активно працюють в провідних ВНЗ, науково-дослідних організаціях, займаються підприємницькою діяльністю.

Тривале існування наукових економічних шкіл у галузі, активне ознайомлення 3 результатами досліджень громадськості, широке запровадження результатів наукового пошуку в практику господарювання свідчать про їх здатність до саморозвитку, що вселяє надію на подальший успішний розвиток галузевих наукових економічних досліджень.

\section{Список використаної літератури}

1. Габович О. Українська фундаментальна наука і європейські цінності / О. Габович, В. Кузнєцов, Н. Семенова. - 2-е вид., доп. - К. : КиєвоМогилян. акад., 2016. - 284 с.

2. Єгоров І. «Стратегія запозичень» і розвиток науки / І. Єгоров, О. Попович, В. Соловйов // Вісник НАН України. - 2003. - № 5. - С. 3-14.

3. Мацевитый Ю. Блеск и нищета отечественной науки. Какая все-таки наука нужна сейчас стране / Ю. Мацевитый, А. Тарелин // 2000. - 2015. 23-29 окт.

4. Єгоров І. Ю. Оцінки результатів наукової діяльності : Традиційні підходи та нови виклики / І. Ю. Єгоров // Наука та наукознавство. - 2014. № 3. - C. 42-47.

5. Єгоров І. Ю. Удосконалення статистики досліджень і розробок : Сучасні тенденції у розвинених країнах світу / І. Ю. Єгоров // Статистика України. - 2013. - № 3. - С. 46-49. 
6. Єфименко Т. І. Концептуальні підходи щодо розвитку механізмів фінансування науки / Т. І. Єфименко // Фінанси України. - 2016. - № 8. C. 9-23.

7. Падучак Б. М. Нові тенденції західного світу у сфері інновацій / Б. М. Падучак // Наука та наукознавство. - 2014. - Т. 10, № 4. - С. 43-49.

8. Семенюк Е. П. Економіка інформаційної сфери : Формування спеціальнонаукового категоріального апарату / Е. П. Семенюк, Я.В.Котляревський, С. І. Князєв, О. В. Мельников // Наука та інновації. - 2017. - Т. 13, № 3. C. 5-21.

9. Бык И. С. Проблемы оранизации и эффективности научной деятельности в вузах / И. С. Бык. - К. : Высшая шк., 1982. - С. 20-55.

10. Библиографический указатель публикаций УНИИПП. 1932-1981 / [сост. : Г. Я. Потерейко, Н. Л. Левина, О. В. Засинчук]. - Львов : Укр. науч.исследоват. ин-т полигр. пром-сти, 1982. -110 с.

11. Видавничо-поліграфічний факультет. 1954-2004 : Нариси історії / [упоряд. В. В. Хоню]. - К. : ВПФ НТУУ «КПІ», 2004. - 208 с.

12. Мельников О. В. Час роботи та звершень (до 80-ліття Української академії друкарства) / О. В. Мельников // Технологія і техніка друкарства. 2010. - № 4(30). - С. 10-30. - Режим доступу : http://ttdruk.vpi.kpi.ua/article/view/55525.

13. Сеньківський В. М. Моделі факторів впливу на наукову кар'єру (на прикладі поліграфічної галузі України) / В. М. Сеньківський, О. В. Мельников // Наук. зап. [Укр. акад. друкарства]. - 2010. - № 1(17). - С. 49-64.

14. Гузела О. І. Дотиком пам'яті : Літературно-біографічні нариси / О. І. Гузела, Л. А. Швайка. - Львів : Укр. акад. друкарства, 2009. - С. 23-32.

15. Мельников О. В. Українська академія друкарства. 1930-2010. Історико-біографічний довідник / О. В. Мельников. - Львів : Укр. акад. друкарства, 2010. - С. 250-252.

16. Концептуальні засади забезпечення сталого розвитку інформаційної сфери України / [Я. В. Котляревський, О.В.Мельников, А. М. Штангрет, Е. П. Семенюк, В. І. Воробйов]. - К. : Центр учбової літератури, 2016. - С. 22-30.

17. Семенюк Э. П. Математизация научного знания и информатика. Вопросы теории / Э. П. Семенюк, В. М. Стасишин // НТИ. Сер. 2. - 1980. № 1. - С. 1-7.

18. Семенюк Э. П. Математизация научного знания и информатика. Прикладные аспекты / Э. П. Семенюк, В. М. Стасишин // НТИ. Сер. 2. 1980. - № 4. - С. 1-8.

19. Роман Машталір. 3 погляду часу : [спогади, бібліографія] / [уклад. : Л. Швайка, О. Гузела]. - Львів : Укр. акад. друкарства, 2001. - 120 с.

20. Дисертації, захищені в Українському поліграфічному інституті ім. Івана Федорова та Українській академії друкарства у 1983-2008 рр. : бібліографічний покажчик / [уклад. : Б. В. Дурняк, О. В. Мельников, О. М. Василишин, О. П. Каширська]. - Львів : Укр. акад. друкарства, 2008. - С. 4.

21. Указ Президента України «Про Державну програму розвитку національного книговидання і преси на період до 2000 року» від 28.02.1995 р. № 158/95 [Електронний ресурс]. - Режим доступу : http://zakon3.rada.gov.ua/ laws/show/158/95 (Дата доступу 01.05.2017 p.). 
22. Ерн-Бишкевич В. Участь технічного комітету «Технологія поліграфії» у створенні та вдосконаленні галузевої нормативно-технічної документації / В. Ерн-Бишкевич, В. Васьків, О. Мельников // Друкарство. - 2006. - № 6(71). - С. 5-8.

23. Холод Зеновія Михайлівна : бібліографічний покажчик / [уклад. : І. І. Малярчук, Л. П. Стеців, Л. А. Швайка]. - Львів : Укр. акад. друкарства, 2016. - $84 \mathrm{c}$.

24. Євген Миколайович Палига : Учений-педагог, управлінець-практик, шанована людина / [упоряд. : І. П. Босак, Л. А. Швайка, С. Г. Янчишин]. Львів : Укр. акад. друкарства, 2014. - 144 с. - (Вчені Укр. акад. друкарства).

25. Штангрет Андрій Михайлович : біобібліографічний покажчик / уклад. О. В. Мельников. - Львів : Укр. акад. друкарства, 2012. - 50 с. - (Вчені Укр. акад. друкарства).

26. Барнич Ю. О. Вклад учених Українського поліграфічного інституту ім. Івана Федорова у розвиток економіки поліграфічної промисловості / Ю. О. Барнич, Р. М. Машталір // Поліграфія і видавнича справа. - 1980. - Вип. 16. - C. 101-109.

27. Барнич Ю. О. Розвиток наукових досліджень в галузі економіки поліграфічної промисловості і видавничої справи в Українському поліграфічному інституті ім. Івана Федорова / Ю. О. Барнич // Поліграфія і видавнича справа. - 1974. - Вип. 10. - С. 38-42.

28. Куслицький Б. Г. Розвиток поліграфії у четвертій п'ятирічці і завдання науково-дослідної роботи / Б. Г. Куслицький // Наук. зап. [Укр. полігр. ін-т]. 1947. - Вип. 8. - С. 43-56.

29. Толстой Г. Д. Основные направления научных исследований в Украинском полиграфическом институте им. Ивана Федоррова / Г. Д. Толстой // Полиграфия и издательское дело. - 1964. - Вып. 1. - С. 5-10.

30. Семенюк Е. П. Інформаційно-комунікаційні аспекти формування i функціонування наукових шкіл видавничо-поліграфічної галузі / Е. П. Семенюк, Я. В. Котляревський, О. В. Мельников // Наука та інновації. - 2016. T. 12, № 2. - С. 71-89.

31. Кизим М. О. Наукові школи / М. О. Кизим, О. М. Тищенко. - Х. : IHЖEK, 2009. - 74 c.

32. Леоненко П. М. Методологія аналізу наукових шкіл у економічній і фінансовій науках / П. М. Леоненко // Фінанси України. - 2013. - № 5. С. 31-49.

33. Опарін В. М. Сучасна українська наукова школа публічних фінансів / В. М. Опарін, В. М. Федосов, П. І. Юхименко // Фінанси України. - 2015. № 11 . - C. 56-87.

34. Дурняк Б. В. Найстаріше фахове видання України з проблем поліграфії та видавничої справи (до 70-річчя «Наукових записок» академії друкарства) / Б. В. Дурняк, О. В. Мельников // Наук. зап. [Укр. акад. друкарства]. - 2011. - № 3(36). - С. 3-6.

35. Науково-технічний збірник «Наукові записки», систематичний анотований покажчик матеріалів, опублікованих у 1939-2009 рр. / [уклад. : Б. В. Дурняк, О. М. Василишин, О. В. Мельников]. - Львів : Укр. акад. друкарства, 2010. - 212 с. 
36. Науково-технічний збірник «Поліграфія і видавнича справа», систематичний покажчик матеріалів, опублікованих у 1964-2004рр. / [уклад. : Б. В. Дурняк, О. В. Мельников, О. М. Василишин]. - Львів : Укр. акад. друкарства, 2009. - 240 с.

\section{References}

1. Habovych, O. \& Kuznietsov, V. \& Semenova, N. (2016). Ukrainska fundamentalna nauka i yevropeiski tsinnosti [Ukrainian basic science and European values]. Kyiv: Kyievo-Mohylian. akad. [in Ukrainian].

2. Yehorov, I. \& Popovych, O. \& Soloviov, V. (2003). 'Stratehiia zapozychen' i rozvytok nauky ['The strategy of borrowing' and the development of science]. Journal of Visnyk NAN Ukrainy - Bulletin of the National Academy of Sciences of Ukraine, 5, 3-14 [in Ukrainian].

3. Macevityj, Ju. \& Tarelin, A. (2015). Blesk i nishheta otechestvennoj nauki. Kakaja vse-taki nauka nuzhna sejchas strane [Shine and poverty of domestic science. What kind of science does the country need now?]. Newspaper of 2000, 23-29 October [in Russian].

4. Yehorov, I. lu. (2014). Otsinky rezultativ naukovoi diialnosti: Tradytsiini pidkhody ta novy vyklyky [Assessment of the results of research: Traditional approaches and new challenges]. Journal of Nauka ta naukoznavstvo Science and Knowledge, 3, 42-47 [in Ukrainian].

5. Yehorov, I. Iu. (2013). Udoskonalennia statystyky doslidzhen i rozrobok: Suchasni tendentsii u rozvynenykh krainakh svitu [Improving of statistics Research and Development: Current Trends in the developed world]. Journal of Statystyka Ukrainy - Statistics of Ukraine, 3, 46-49 [in Ukrainian].

6. Yefymenko, T. I. (2016). Kontseptualni pidkhody shchodo rozvytku mekhanizmiv finansuvannia nauky [Conceptual approaches to development of financing mechanisms of science]. Finansy Ukrainy - Finances of Ukraine, 8, 9-23 [in Ukrainian].

7. Paduchak, B. M. (2014). Novi tendentsii zakhidnoho svitu u sferi innovatsii [New trends in the Western world in innovation]. Journal of Nauka ta naukoznavstvo - Science and Knowledge, Vol. 10, No 4, 43-49 [in Ukrainian].

8. Semeniuk, E. P. \& Kotliarevskyi, la. V. \& Kniaziev, S. I. \& Melnykov, O. V. (2017). Ekonomika informatsiinoi sfery: Formuvannia spetsialnonaukovoho katehorialnoho aparatu [Economics of information sphere: Formation of special-scientific categorial apparatus]. Journal of Nauka ta innovatsii - Science and innovations, Vol. 13, No 3, 5-21 [in Ukrainian].

9. Byk, I. S. (1982). Problemy oranizacii i jeffektivnosti nauchnoj dejatel'nosti v vuzah [Problems of organization and effectiveness of scientific activity in universities]. Kiev: Vysshaja shk. [in Russian].

10. (1982). Bibliograficheskij ukazatel' publikacij UNIIPP. 1932-1981 [Bibliographic index of publications USDIPP. 1932-1981]. L'vov: Ukr. nauch.-issledovat. in-t poligr. prom-sti [in Russian].

11. (2004). Vydavnycho-polihrafichnyi fakultet. 1954-2004: Narysy istorii [Publishing and Printing Faculty. 1954-2004: Essays on history]. Kyiv: VPF NTUU 'KPI' [in Ukrainian].

12. Melnykov, O. V. (2010). Chas roboty ta zvershen (do 80-littia Ukrainskoi akademii drukarstva) [Time of work and achievements (to the 80th anniversary 
of the Ukrainian Academy of Printing)]. Journal of Tekhnolohiia i tekhnika drukarstva - Technology and technique of typography, 4(30), 10-30. Retrieved from http://ttdruk.vpi.kpi.ua/article/view/55525 [in Ukrainian].

13. Senkivskyi, V. M. \& Melnykov, O. V. (2010). Modeli faktoriv vplyvu na naukovu kar'ieru (na prykladi polihrafichnoi haluzi Ukrainy) [Models of factors influencing on academic career (for example, printing industry of Ukraine)]. Journal of Naukovi zapysky - Scientific notes, 1(17), 49-64 [in Ukrainian].

14. Huzela, O. I. \& Shvaika, L. A. (2009). Dotykom pam'iati: Literaturno-biohrafichni narysy [Touch of memory: Literary and biographical sketches]. Lviv: Ukr. akad. drukarstva [in Ukrainian].

15. Melnykov, O. V. (2010). Ukrainska akademiia drukarstva. 1930-2010. Istoryko-biohrafichnyi dovidnyk [Ukrainian Academy of Printing. 1930-2010. Historical and Biographical Directory]. Lviv: Ukr. akad. drukarstva [in Ukrainian].

16. Kotliarevskyi, la. V. \& Melnykov, O. V. \& Shtanhret, A. M. \& Semeniuk, E. P. \& Vorobiov, V. I. (2016). Kontseptualni zasady zabezpechennia staloho rozvytku informatsiinoi sfery Ukrainy [Conceptual framework for sustainable development of the information sphere of Ukraine]. Kyiv: Tsentr uchbovoi literatury [in Ukrainian].

17. Semenjuk, Je. P. \& Stasishin, V. M. (1980). Matematizacija nauchnogo znanija i informatika. Voprosy teorii [Mathematicalization of scientific knowledge and informatics. Theory questions]. Journal of NTI. Ser. 2, 1, 1-7 [in Russian].

18. Semenjuk, Je. P. \& Stasishin, V. M. (1980). Matematizacija nauchnogo znanija i informatika. Prikladnye aspekty [Mathematicalization of scientific knowledge and informatics. Applied aspects]. Journal of NTI. Ser. 2, 4, 1-8 [in Russian].

19. (2001). Roman Mashtalir. Z pohliadu chasu (spohady, bibliohrafiia) [Roman Mashtalir. In terms of time (memoirs, bibliography)]. Lviv: Ukr. akad. drukarstva [in Ukrainian].

20. (2008). Dysertatsii, zakhyshcheni v Ukrainskomu polihrafichnomu instytuti im. Ivana Fedorova ta Ukrainskii akademii drukarstva u 1983-2008 rr. [Theses are protected in Ivan Fedorov Ukrainian Polygraphic Institute and Ukrainian Academy of Printing in the 1983-2008]. Lviv: Ukr. akad. drukarstva [in Ukrainian].

21. Ukaz Prezydenta Ukrainy 'Pro Derzhavnu prohramu rozvytku natsionalnoho knyhovydannia i presy na period do 2000 roku' [The Decree of the President of Ukraine 'On State Program of development of national publishing and media for the period until 2000']. Dated 28.02.1995. \# 158/95. Retrieved from http://zakon3.rada.gov.ua/laws/show/158/95. (Last accessed: 01.05. 2017) [in Ukrainian].

22. Ern-Byshkevych, V. \& Vaskiv, V. \& Melnykov, O. (2006). Uchast tekhnichnoho komitetu 'Tekhnolohiia polihrafii' u stvorenni ta vdoskonalenni haluzevoi normatyvno-tekhnichnoi dokumentatsii [Participation of Technical Committee 'Printing Technology' in building and improving the sector of technical standards]. Journal of Drukarstvo - Typography, 6(71), 5-8 [in Ukrainian].

23. (2016). Kholod Zenoviia Mykhailivna: bibliohrafichnyi pokazhchyk [Kholod Zenoviia Mykhailivna: bibliography]. Lviv: Ukr. akad. drukarstva [in Ukrainian].

24. (2014). Yevhen Mykolaiovych Palyha: Uchenyi-pedahoh, upravlinetspraktyk, shanovana liudyna [Yevhen Mykolaiovych Palyha: scientist, teacher, manager practices, respected person]. Lviv: Ukr. akad. drukarstva [in Ukrainian]. 
25. (2012). Shtanhret Andrii Mykhailovych: biobibliohrafichnyi pokazhchyk [Shtanhret Andrii Mykhailovych: bibliographic index]. Lviv: Ukr. akad. drukarstva [in Ukrainian].

26. Barnych, Iu. O. \& Mashtalir, R. M. (1980). Vklad uchenykh Ukrainskoho polihrafichnoho instytutu im. Ivana Fedorova u rozvytok ekonomiky polihrafichnoi promyslovosti [The contribution of scientists of Ivan Fedorov Ukrainian Printing Institute to the economic development of the printing industry]. Journal of Polihrafiia i vydavnycha sprava - Polygraphy and publishing, 16, 101-109 [in Ukrainian].

27. Barnych, lu. O. (1974). Rozvytok naukovykh doslidzhen v haluzi ekonomiky polihrafichnoi promyslovosti i vydavnychoi spravy $v$ Ukrainskomu polihrafichnomu instytuti im. Ivana Fedorova [The development of research in economics printing industry and publishing in Ivan Fedorov Ukrainian Polygraphic Institute]. Journal of Polihrafiia i vydavnycha sprava - Polygraphy and publishing, 10, 38-42 [in Ukrainian].

28. Kuslytskyi, B. H. (1947). Rozvytok polihrafii u chetvertii p'iatyrichtsi i zavdannia naukovo-doslidnoi roboty [The development of printing in the fourth fiveyear objectives and research]. Journal of Nauk. zap. - Scientific Notes, 8, 43-56 [in Ukrainian].

29. Tolstoj, G. D. (1964). Osnovnye napravlenija nauchnyh issledovanij v Ukrainskom poligraficheskom institute im. Ivana Fedorrova [Main direction of research in Ivan Fedorov Ukrainian Polygraph Institute]. Journal of Poligrafija $i$ izdatel'skoe delo - Printing and Publishing, 1, 5-10 [in Russian].

30. Semeniuk, E. P. \& Kotliarevskyi, la. V. \& Melnykov, O. V. (2016). Informatsiino-komunikatsiini aspekty formuvannia i funktsionuvannia naukovykh shkil vydavnycho-polihrafichnoi haluzi [Information and communication aspects of the functioning of scientific schools and publishing and printing industry]. Journal of Nauka ta innovatsii - Science and innovations, Vol. 12, No 2, 71-89 [in Ukrainian].

31. Kyzym, M. O. \& Tyshchenko, O. M. (2009). Naukovi shkoly [Scientific schools]. Kharkiv: INZhEK [in Ukrainian].

32. Leonenko, P. M. (2013). Metodolohiia analizu naukovykh shkil u ekonomichnii i finansovii naukakh [Methodology the analysis of scientific schools in economic and financial sciences]. Journal of Finansy Ukrainy - Finance of Ukraine, 5, 31-49 [in Ukrainian].

33. Oparin, V. M. \& Fedosov, V. M. \& Yukhymenko, P. I. (2015). Suchasna ukrainska naukova shkola publichnykh finansiv [Modern Ukrainian scientific school of public finance]. Journal of Finansy Ukrainy - Finance of Ukraine, 11, 56-87 [in Ukrainian].

34. Durniak, B. V. \& Melnykov, O. V. (2011). Naistarishe fakhove vydannia Ukrainy z problem polihrafii ta vydavnychoi spravy (do 70-richchia 'Naukovykh zapysok' akademii drukarstva) [The oldest professional journal of Ukraine about problems of printing and publishing (the 70th anniversary of 'Scientific Notes' of Academy of Printing]. Journal of Nauk. zap. - Scientific notes, 3(36), 3-6 [in Ukrainian].

35. (2010). Naukovo-tekhnichnyi zbirnyk 'Naukovi zapysky', systematychnyi anotovanyi pokazhchyk materialiv, opublikovanykh u 1939-2009 rr. [Scientific and technical collection 'Scientific Notes', systematic annotated index of materials published in the 1939-2009]. Lviv: Ukr. akad. drukarstva [in Ukrainian]. 
36. (2009). Naukovo-tekhnichnyi zbirnyk 'Polihrafiia i vydavnycha sprava', systematychnyi pokazhchyk materialiv, opublikovanykh u 1964-2004 rr. [Scientific and technical collection 'Printing and Publishing', systematic materials index, published in the 1964-2004]. Lviv: Ukr. akad. drukarstva [in Ukrainian].

Авторы на примере науки, изучающей экономику информационной сферы и ее составляющих, хотели показать, как происходит фундаментализация науки, на первый взгляд сугубо прикладной. Этот процесс заключается в росте удельного веса ее теоретических составляющих, совершенствовании понятийного и концептуального аппарата, построении моделей ее развития, выявлении законов ее функционирования и, как следствие, в получении нового методологического знания. Необходимым условием этого процесса является также наличие соответствующих научных школ. Анализ вопросов, связанных с деятельностью научных школ, следует вести по схеме "теория-школа-направление-течение", где каждая следующая составляющая шире предыдущей. Впрочем, исследователи не всегда четко придерживаются необходимой субординации в терминологии: понятие теорий, школ и направлений часто смешиваются и отождествляются. Кроме того, не всегда делается упор на продолжительности и преемственности научных коллективов. В нашем случае исследования ведутся в течение восьмидесяти лет. Результатом этой деятельности (в рамках научного направления «Экономические исследования издательскополиграфической отрасли Украины”) стало появление четырех научных школ профессоров А. М. Левина,

Р. М. Машталера, П. Е. Беленького и академика М. И. Долишнего. Комплексный системный подход к решению проблем издательско-полиграфической отрасли, автоматизированные системы управления производством, моделирование производственных систем - вот далеко не полный перечень направлений исследований, которые имеют важное научное и прикладное значение.

Ключевые слова: информационная сфера; издательскополиграфическая отрасль; научная школа; прикладные и фундаментальные исследования.

The authors, using the example of a science studying the economy of the information sphere and its components, wanted to show how the fundamentalization of science that is purely applied at first glance occurs. This process is based on the growth of the specific weight of its theoretical compo-

nents, the improvement of the conceptual apparatus, 
the construction of models for its development, the identifica-

tion of the laws of its functioning and, as a consequence, the obtaining of new methodological knowledge. A necessary condition for this process is also the availability of the appro-

priate scientific schools. Analysis of the issues related to the activities of scientific schools should be conducted according to the scheme 'theory-school-direction-current', where each of the following components is wider than the previous one. However, researchers do not always clearly adhere to the necessary subordination in terminology: the notion of theories, schools, and directions is often confused and identified. In addition, there is not always an emphasis on the duration and continuity of research teams. In our case, the research is conducted for eighty years. The result of this activity (within the framework of the scientific direction 'Economic Studies of the Publishing and Printing Industry of Ukraine') was the emergence of four scientific schools of Professors A. M. Levin, R. M. Mashtalir, P. Iu. Bielienkyi, and Academician M. I. Dolishnyi. An integrated system approach to solving the problems of the publishing and printing industry, automated production management systems, modeling of production systems is far from a complete list of research areas that have important scientific and applied significance.

Keywords: information sphere; publishing and printing industry; scientific school; applied and fundamental research. 